\title{
Exposure to Domestic and Community Violence and Subjective Well-Being in Adolescents $^{1}$
}

\author{
Doralúcia Gil da Silva ${ }^{2}$ \\ Universidade Federal do Rio Grande do Sul, \\ Porto Alegre-RS, Brazil
}

\author{
Débora Dalbosco Dell'Aglio \\ Universidade Federal do Rio Grande do Sul, \\ Porto Alegre-RS, Brazil
}

\begin{abstract}
There is major exposure to domestic and community violence during adolescence, which has been negatively related to wellbeing. This work aimed to identify relationships between domestic and community violence and the levels of subjective well-being perceived by adolescents, considering sex and age. The participants were 426 adolescents from public schools in the south of Brazil; $62 \%$ were girls, with a mean age of 14.91 years old $(S D=1.65)$, who answered one instrument about exposure to violence and another about well-being. Results indicated greater domestic violence exposure among girls and greater community exposure among boys. The age range from 16 to 18 years old was the most exposed to domestic violence. Boys reported greater well-being and less negative affect. Differences in violence exposure may be related to roles of gender in our society. Well-being promotion is highlighted as a resource for confronting violence among adolescents.
\end{abstract}

Keywords: adolescence, violence, subjective well-being

\section{Exposição à Violência Intrafamiliar e Extrafamiliar e Bem-Estar Subjetivo em Adolescentes}

\begin{abstract}
Resumo: Estudos indicam que na adolescência há maior exposição à violência intrafamiliar e extrafamiliar, o que tem sido relacionado negativamente ao bem-estar. Este estudo teve por objetivo investigar as relações entre a exposição à violência nos contextos intrafamiliar e extrafamiliar e bem-estar subjetivo, considerando as variáveis sexo e idade. Participaram 426 adolescentes de escolas públicas do sul do Brasil, sendo $62 \%$ do sexo feminino, com média de idade de 14,91 anos $(D P=1,65)$, que responderam instrumentos sobre exposição à violência e bem-estar. Os resultados indicaram maior exposição à violência intrafamiliar entre meninas e maior exposição à violência extrafamiliar entre meninos, sendo a faixa etária de 16 a 18 anos mais exposta à violência intrafamiliar. Os meninos apresentaram maiores níveis de bem-estar e menores níveis de afetos negativos. Diferenças na exposição à violência podem estar relacionadas a papéis de gênero presentes em nossa sociedade. Destaca-se a promoção de bem-estar subjetivo como recurso para o enfrentamento da violência entre adolescentes.
\end{abstract}

Palavras-chave: adolescência, violência, bem-estar subjetivo

\section{Exposición a la Violencia Intrafamiliar y Extrafamiliar y Bienestar Subjetivo en Adolescentes}

\begin{abstract}
Resumen: Estudios indican que en adolescencia hay uma mayor exposición a situaciones de violencia intra y extra familiar, relacionando-se negativamente a bienestar. Este estudio tuvo como objetivo identificar relaciones entre la violencia intrafamiliar y extrafamiliar y los niveles de bienestar subjetivo percibidos por los adolescentes, teniendo en cuenta sexo y edad. Participaron 426 adolescentes de escuelas publicas del sul de Brasil, $62 \%$ mujeres, con média de edad de 14,91 años $(D E=1,65)$, que respondieron instrumentos sobre exposición à violencia y bienestar. Los resultados indicaron mayor exposición à violencia intrafamiliar entre las mujeres y maior exposición à violencia extrafamiliar entre los niños. El grupo de edad 16 a 18 años fue el más expuesto à violencia intrafamiliar. Los niños mostraron um mayor bienestar y niveles más bajos de afectos negativos. Diferencias en la exposición à violencia pueden estar relacionadas a roles de género de nuestra sociedad. Destaca-se la promoción de bienestar subjectivo como recurso para el enfrentamiento de la violencia entre adolescentes.
\end{abstract}

Palabras clave: adolescencia, violencia, bienestar subjetivo

Violence has been defined by the World Health Organization (Krug, Dahlberg, Mercy, Zwi, \& Lozano, 2002) as practices against oneself, against another person or against a group which result in death, suffering, harm, impaired development or privation, and which can occur in different

\footnotetext{
${ }^{1}$ Article derived from the master's thesis of the first author under the supervision of the second author, presented in 2015, in the Graduate Program in Psychology of the Universidade Federal do Rio Grande do Sul.

${ }^{2}$ Correspondence address:

Doralúcia Gil da Silva. Rua Ramiro Barcellos, 2600, sala 115. CEP 90035003. Porto Alegre-RS, Brazil. E-mail: doralu.gil@gmail.com
}

contexts, including the use of physical force or of power, using threats, intimidation or neglect. The World Health Organization (WHO; 2014a) has maintained this definition and indicates that in many countries, violence continues to be a major challenge to public health.

This study addresses interpersonal violence, which is divided between intrafamily and extrafamily violence. The former is also known as domestic violence and is perpetrated by somebody who maintains significant bonds with the victim. Within this classification one must consider the family violence in which any action or omission based in issues of 
gender occurs - configuring gender violence (Law n. 11.340, 2006). The second form, on the other hand, also known as community violence, occurs when the aggressor does not belong to the ambit of the family relationships. It generally occurs in other locales frequented by young people (school, neighborhood, transport, workplaces and health institutions, among others), among which the most common examples are acts of aggression, assaults, rapes and robbery, with or without the presence of arms (Krug et al., 2002).

A WHO report (2014b) revealed that in 2012 more than 1 million adolescents died worldwide as a result of problems related to violence. In Brazil, likewise, in adolescence there are high rates of mortality from violent causes, constituting a public health problem (Ministry of Health, 2010). In one survey undertaken with 1,223 students from state schools in the South of Brazil, aged from 13 to 20 years old, it was observed that $99.7 \%$ of them had experienced some type of violence in the community, it being the case that $70.9 \%$ stated that they had been direct victims (Zavaschi, Benetti, Polanczyk, Solés, \& Sanchotene, 2002).

Faced with such data, one must consider the effects of exposure to violence in adolescence. Among the consequences, emphasis is placed on those relating to issues of young people's mental health and well-being (WHO, 2014b). Indeed, inverse associations may be observed between components of well-being and violence, such as those demonstrated in the study of Callahan, Tolman and Saunders (2003), which assessed the relationship between violence between adolescent boyfriends and girlfriends and well-being, in a sample with 190 students from Senior High School of both sexes, using questionnaires. In that study, girls and boys reported high levels of interpersonal violence, and these were related to low levels of life satisfaction (LS).

Subjective well-being, in its turn, refers to a cognitive and emotional evaluation which a person makes regarding their life. The cognitive evaluation corresponds to the evaluation of life satisfaction globally or based on domains such as family, school or relationships (Diener, 1984). The affective factor covers the positive and negative affects. The positive affect (PA) is defined as the extent to which an individual feels active and enthusiastic, while negative affect (NA) corresponds to the extent to which a person feels states of adverse mood such as guilt or anger (Watson, Clark, \& Tellegen, 1988).

Studies point to variables considered to be fundamental in assessing well-being, among which one finds sex, regarding which there is as yet no consensus. One European study undertaken with 2,400 adolescents found relevant differences in life satisfaction between the sexes (Reina, Oliva, \& Parra, 2010). At the same time, the data from other studies have not revealed these differences, as in Latin American studies (Benatuil, 2004; Sarriera et al., 2012). In another study, undertaken with 271 Argentinian adolescents, significant differences by sex and age were not found, although variables such as personal links and acceptance of oneself were capable of differentiating young people with greater or lesser levels of well-being (Benatuil, 2004).

In the context of the South of Brazil, the difference of the levels of well-being between the sexes was also not identified in a study with 188 students from year eight of state schools (Strelhow, Bueno, \& Câmara, 2010). However, Serafini, and Bandeira (2011) undertook a study with 502 adolescents from public schools and observed that the girls were shown to be more satisfied with their relationships with friends, colleagues and teachers and with the school activities. For the boys, the satisfaction in the relationship with the father and closeness with him was significantly greater in comparison with the girls. Camargo, Abaid, and Giacomoni (2011) found that the family category appeared as more important for the girls. The authors discussed this result in terms of the behavior of discussing and sharing experiences and feelings being more common within the female sex. Another study which found difference between the sexes was that of Vera et al. (2008), undertaken in the United States with 151 Afro-American adolescents and adolescents from other ethnic groups, from 12 to 15 years old, from state schools. In that study, sex significantly explained the variation in the negative affects, with the boys presenting lower rates.

Age also influences well-being, a reduction of the levels of satisfaction has been observed as the age of the adolescent increases, according to research undertaken in five countries on different continents (Coenders, Casas, Figuer, \& González, 2005). The study of Sarriera et al. (2012), with 640 Argentinian and Brazilian adolescents, indicated that from 13 to 16 years old, there is a progressive reduction in well-being, which was discussed in terms of the young person passing through uncertain and challenging situations as he or she ages - such as choosing a career - which lead to lower life satisfaction.

Bearing in mind the high rates of exposure to violence in adolescence, and the protective role which subjective well-being may perform in these cases (Park, 2004; Sarriera et al., 2012), it becomes relevant to study the relationships between these two variables. As a result, this study aimed to investigate the relationships between the exposure to violence in the intrafamily and extrafamily contexts and subjective well-being, considering the variables of sex and age.

\section{Method}

\section{Participants}

A total of 426 adolescents participated in this study, aged between 12 and 18 years old $(M=14.91 ; S D=1.65)$, of both sexes ( $62 \%$ female). The participants were between the sixth year of Basic Education and the third year of Senior High School, in schools of the public network, in the south of Brazil.

\section{Instruments}

Sociodemographic Data Questionnaire. This investigates data such as age, sex, school year, work, family configuration and having to repeat a school year, among others. This questionnaire was developed by the authors for use in the present study.

Exposure to Intra- and Extrafamily Violence. These variables were evaluated based on two questions taken 
from the Brazilian Youth Questionnaire (Questionário da Juventude Brasileira; Dell'Aglio, Koller, Cerqueira-Santos, \& Colaço, 2011) which investigate situations of physical, psychological and sexual abuse in the intra- and extrafamily context, containing five items answered dichotomously $(0=$ No, $1=$ Yes $)$. For the final score, the items of family violence and extrafamily violence were counted, adding together the number of positive responses in each question, with variation from 0 to 5 points being possible.

Multidimensional Scale of Life Satisfaction for Adolescents (Escala Multidimensional de Satisfação de Vida para Adolescentes-EMSVA; Segabinazi, Giacomoni, Dias, Teixeira, \& Moraes, 2010). This scale is composed of 52 items which evaluate seven dimensions of the life satisfaction (LS) of adolescents: family, self, school, compared self, nonviolence, self-efficacy and friendship. It has a five point Likert scale, varying from 1 (not even a little) to 5 (very much). The original study (Segabinazi et al., 2010) found an adequate internal consistency for the scale $(\alpha=.93)$.

Positive and Negative Affects Scale for Adolescents (Escala de Afetos Positivos e Negativos para AdolescentesEAPNA; Segabinazi et al., 2012). This scale is composed of 32 adjectives which describe subjective affective states, with responses on a five point Likert scale, varying from not even a little to very much. The study (Segabinazi et al., 2012) demonstrated adequate levels of internal consistency evaluated through the Cronbach's alpha (.88 for PA and for NA). The EMSVA and the EAPNA were used for the evaluation of the subjective well-being, through the composition of an index.

\section{Procedure}

Data collection. The study was undertaken in public schools selected by convenience, in different regions of the city of Porto Alegre. The adolescents were invited to participate, and the instruments were applied collectively by the research team in the schools' classrooms, lasting approximately 45 minutes.

Data analysis. The data were typed in the SPSS program and the psychometric properties of the instrument were ascertained through the scales' rate of internal consistency (Cronbach alpha). Descriptive and inferential statistical analyses were undertaken (Student's t-tests, Principle Component Analyses and Pearson Correlations). The level of significance adopted was $5 \%(p \leq .05)$. The correlations were undertaken between the variables of family violence, extrafamily violence and the Subjective Well-being Index and its components.

\section{Ethical Considerations}

The ethical aspects which ensure the participants' integrity were guaranteed, being based upon Resolution n. 466 (Ministry of Health, 2013). The management of the schools signed the Institution's Terms of Agreement. The parents or guardians of the adolescents participating signed the Informed Consent Form, and the young people themselves signed the Assent Form. The study was approved by the Research Ethics Committee of the Instituto de Psicologia of the Universidade Federal do Rio Grande do Sul, on March 14th, 2014 (CAAE n. 22080914.1.0000.5334).

\section{Results}

Firstly, the psychometric characteristics of the scales used were observed. The Multidimensional Scale of Life Satisfaction presented scores between 100 and $256(M=$ 199.6; $S D=28.11)$ and satisfactory internal consistency $(\alpha$ $=.87)$. The Positive Affects Scale presented scores between 16 and $70(M=50.91 ; S D=10.88)$ and internal consistency of .88. The Negative Affects Scale presented scores between 14 and $63(M=24.77 ; S D=10.08)$ and internal consistency of .89. All the indexes were considered adequate.

Regarding the question on intra- and extrafamily violence, the scores varied from 0 to $5(M=0.64 ; S D=0.99)$ for intrafamily violence and between 0 and $3(M=0.61 ; S D$ $=0.81$ ) for extrafamily violence. Table 1 presents the data for exposure to intra- and extrafamily violence by sex and age range (range 1: 12 to 15 years old, $n=255$; range 2: 16 to 18 years old, $n=170$ ). One Student's t-test indicated that the girls had a higher mean of exposure to intrafamily violence, while the boys had a higher mean in exposure to extrafamily violence, with a significant difference $(t=$ -3.11; $d f=414.13 ; p<.002$ and $t=3.37 ; d f=292.92 ; p$ $<.001$, respectively). The analysis by age range revealed that there was a greater exposure to intrafamily violence among the older adolescents, with a statistically significant difference $(t=-3.26 ; d f=423 ; p<.001)$.

Table 1

Means of Violence, by Sex and Age Range

\begin{tabular}{lccccc}
\hline Variable & & Male & Fem. & $\begin{array}{c}12 \text { to } 15 \\
\text { years }\end{array}$ & $\begin{array}{c}16 \text { to } 18 \\
\text { years }\end{array}$ \\
\hline $\begin{array}{l}\text { Intrafamily } \\
\text { violence }\end{array}$ & $M$ & 0.46 & 0.75 & 0.51 & 0.83 \\
& $S D$ & 0.77 & 1.09 & 0.98 & 0.99 \\
$\begin{array}{l}\text { Extrafamily } \\
\text { violence }\end{array}$ & $M$ & 0.79 & 0.50 & 0.57 & 0.68 \\
Total violence & $S D$ & 0.89 & 0.73 & 0.77 & 0.86 \\
& $M$ & 1.26 & 1.25 & 1.08 & 1.52 \\
& $S D$ & 1.39 & 1.56 & 1.44 & 1.55 \\
\hline
\end{tabular}

In order to identify the levels of well-being, an Index of Well-being (IWB) was constructed, using the standardized scores of the EMSVA added to the standardized scores of the EAPNA, with the items of negative affects being inverted for the calculation. In order to construct the IWB, a Principle Components Analysis was undertaken, as this makes it possible to create an index based on the empirical valences of its components, verifying the weight of each one for the index (Field, 2009). The components used in the IWB arise from the theoretical model proposed by Diener (1984) and 
Diener, Suh, Lucas and Smith (1999), which considers the variables of life satisfaction, positive affects, and negative affects, for making up the subjective well-being. Table 2 presents the raw and standardized minimum and maximum scores of each component of the IWB.

Table 2

Raw and Standardized Scores of Life Satisfaction, Positive Affects, Negative Affects and of the Index of Well-Being

\begin{tabular}{lcccc}
\hline & $\begin{array}{c}\text { Life } \\
\text { Satisfaction }\end{array}$ & $\begin{array}{c}\text { Positive } \\
\text { Affects }\end{array}$ & $\begin{array}{c}\text { Negative } \\
\text { Affects }\end{array}$ & $\begin{array}{c}\text { Index of } \\
\text { Well-Being }\end{array}$ \\
\hline Raw score & & & & \\
Min. & 100 & 16 & 14 & 69 \\
Max. & 256 & 70 & 63 & 311 \\
$M$ & 199.60 & 50.91 & 24.77 & 225.72 \\
$S D$ & 28.11 & 10.88 & 10.08 & 42.88 \\
Standardized & & & & \\
score & & & & \\
Min. & -1.52 & -2.42 & -0.86 & -3.37 \\
Max. & 1.73 & 1.94 & 1.41 & 2.78 \\
$M$ & -0.008 & -0.01 & 0.01 & -0.009 \\
$S D$ & 0.56 & 0.76 & 0.44 & 1.004 \\
\hline
\end{tabular}

Table 3 presents the standardized means for LS, PA, NA and the IWB, by sex and age range. Analyses were undertaken with the Student's t-test in order to ascertain differences in the variables investigated. In relation to the NA, the boys presented lower levels than the girls, there being significant difference $(t=-4.06 ; d f=424 ; p<.0001)$. Regarding the differences by age ranges, the results did not reveal statistically significant differences. In relation to the IWB, it was observed that the boys presented greater subjective wellbeing in comparison with the girls, with significant difference $(t=2.76 ; d f=424 ; p=.006)$.

Table 3

Means of LS, PA, NA and IWB by Sex and Age Range

\begin{tabular}{lccccc}
\hline & & Male & Female & $\begin{array}{c}12-15 \\
\text { years }\end{array}$ & $\begin{array}{c}16-18 \\
\text { years }\end{array}$ \\
\hline Life Satisfaction & $M$ & 0.08 & -0.05 & 0.004 & -0.008 \\
& $S D$ & 0.54 & 0.57 & 0.57 & 0.54 \\
Positive Affects & $M$ & 0.03 & -0.04 & -0.01 & -0.01 \\
& $S D$ & 0.71 & 0.79 & 0.79 & 0.73 \\
Negative Affects & $M$ & -0.09 & 0.08 & 0.007 & 0.03 \\
& $S D$ & 0.42 & 0.44 & 0.47 & 0.40 \\
Index of & $M$ & 0.16 & -0.10 & 0.01 & -0.02 \\
Well-Being & $S D$ & 0.93 & 1.02 & 1.04 & 0.93 \\
\hline
\end{tabular}

In order to ascertain the relationships between exposure to violence and well-being, the Pearson correlations were used. Table 4 presents the results of these correlations.
Table 4

Correlations Between Violence and the Variables Investigated

\begin{tabular}{lcccc}
\hline & $\begin{array}{c}\text { Positive } \\
\text { Affects }\end{array}$ & $\begin{array}{c}\text { Negative } \\
\text { Affects }\end{array}$ & $\begin{array}{c}\text { Life } \\
\text { Satisfaction }\end{array}$ & $\begin{array}{c}\text { Index of } \\
\text { Well-being }\end{array}$ \\
\hline $\begin{array}{l}\text { Intrafamily } \\
\text { violence }\end{array}$ & $-.16^{*}$ & $.34^{*}$ & $-.32^{*}$ & $-.32^{*}$ \\
$\begin{array}{l}\text { Extrafamily } \\
\text { violence }\end{array}$ & -.07 & $.26^{*}$ & $-.24^{*}$ & $-.23^{*}$ \\
$\begin{array}{l}\text { Total violence } \\
\text { Tole }\end{array}$ & $-.14^{*}$ & $.36^{*}$ & $-.35^{*}$ & $-.34^{*}$ \\
\hline
\end{tabular}

${ }^{*} p=.01$.

Significant correlations were found between exposure to intra- and extrafamily violence and subjective well-being, as well as with the variables which make this up, except for between extrafamily violence and positive affects. The highest rate of correlation occurred between total violence and negative affects.

\section{Discussion}

Results of the analysis of the exposure to violence in relation to age indicated that the young people from 16 to 18 years old presented higher means of exposure to intrafamily violence. This result is shown to be contentious in relation to the data from other studies which show greater exposure to extrafamily violence among older adolescents, associated with the greater time that they spend out of the house and greater exposure to situations of risk (Coutinho, Santos, Folmer, \& Puntel, 2013; Farias Júnior et al., 2009). However, the greater occurrence of intrafamily violence among the older adolescents observed in this study may be understood based on developmental issues. Over the course of adolescence, there is a seeking for a social place and for professional projects, accompanied by greater autonomy in relation to the family, which may lead to conflicts in the family environment (Sarriera et al., 2012).

In relation to the differences in exposure to violence between the sexes, the results showed greater victimization of boys in the extrafamily context, which supports data from other surveys (Ministry of Health, 2010). This may possibly occur due to the process of turning towards the social environment and spending more time away from home, a fact which is observed more and encouraged among male youngsters. In addition to this, boys present more aggressive behaviors and behaviors of risk, which may expose them to violent situations (Benetti et al., 2006; Zavaschi et al., 2002).

The greater occurrence of intrafamily violence in the girls' group, found in this study, was also observed in other Brazilian studies (Ministry of Health, 2010). This data indicates that the girls are more vulnerable to victimization in the domestic environment in comparison with the boys, which may be explained by gender stereotypes, related to the process of socialization which involves the function of socially constructed roles (Bueno, 2006). Girls are encouraged more to remain at home so that they can undertake domestic roles, which are perceived as typically female. In their turn, the 
boys are encouraged to leave home and help with the family finances, these characteristics being perceived as hoped for by the adolescents themselves (Saffioti, 2008; TraversoYépez, \& Pinheiro, 2005). In this way, these conceptions can culminate in gender violence, which, with greater emphasis on the family context, make the women more vulnerable. The differences by sex observed may be explained based on certain hypotheses. The exposure to family violence, in the case of the girls, may explain the lower perception of the positive aspects, as the positive component of the well-being is related to living in a protective environment (Bastian, Kuppens, De Roover, \& Diener, 2014). Besides this, girls typically are more attentive to internal states than are boys (Poletto \& Koller, 2011), which may also explain the greater experiencing of negative affects by the girls. The result that there was no correlation between extrafamily violence and positive affects may indicate that when the violence is perpetrated by strangers it does not affect so much the levels of positive affect as when it is perpetrated in the family environment. It may be thought that the positive affects are more influenced by the type of link established between the perpetrator and victim, as, when the violence is imposed by somebody close and who should supposedly exercise the role of protection and care for the adolescent, the effect may be worse. This aspect is related to the specific characteristics of intrafamily violence, such as the use of the close relationship and relationship of trust between the victim and the abuser, principally in cases of sexual violence, in which the dynamic of the secret is present (Habigzang, Ramos, \& Koller, 2011; Nurcombe, 2000).

In the present study, it was observed that the adolescents present high exposure to violence. In relation to the correlations found, the results are similar to previous findings which indicate an inverse association between violence and subjective well-being (Callahan et al., 2003; Park, 2004; Sarriera et al., 2012). At the same time, in considering that the greater perception of subjective well-being by the young people is associated with health and quality of life, it is emphasized that its promotion may serve as a resource for confronting and preventing violence among the young. Such interventions could be the target of investigation of further studies. As an example, among the prevention strategies one can cite the development and training of social skills (Martins et al., 2014), considering that in some cases, the violence occurs as an attempt to resolve conflicts resulting from the behavioral repertoire in poor social skills (Martínez González, Inglés Saura, Piqueras Rodríguez, \& Oblitas Guadalupe, 2010). There are, furthermore, the actions which seek to prevent the repetition of violence by the young person who was exposed to some violent situation (Martínez González et al., 2010).

Finally, returning to the principal findings of the present study, emphasis is placed on differences by age and sex, with greater intrafamily violence among the older adolescents, greater intrafamily violence among the girls, and greater extrafamily violence among the boys. These results evidence aspects related to the search for autonomy, as well as differences related to gender stereotypes, which are expressed through the violence. Furthermore, boys present higher levels of well-being and lower levels of negative affects than do the girls, which also suggests differences between the sexes in the way of experiencing and expressing affects.

In relation to this study's limitations, it must be pointed out that violence is a complex phenomenon and that different factors are involved in it. This being the case, the results described here must be interpreted with care, as the measure used for ascertaining the adolescents' exposure to violence presents limitations, due to containing questions which only capture certain aspects of some types of violence, whose answers were closed, and filled out by the participant himself or herself at a single point in time. Other forms of violence, as well as other characteristics of the contexts in which this occurs, could have been evaluated better by more detailed instruments, or, further, in studies with qualitative methodologies such as that of Mosavel, Ahmed, and Simon (2012). It is important to be cautious in inferring causal relationships between violence and well-being, as the measurements of association used in this study are not appropriate for this type of conclusion. It may be thought that exposure to violence may both reduce the levels of well-being, due to the negative consequences that this can bring, and at the same time could raise the hypothesis that adolescents who already present lower levels of well-being may be more vulnerable to victimization, as in the discussion made by Callahan et al. (2003).

It is suggested that further investigative works could adopt a longitudinal design, with systematic monitoring of the adolescents, in such a way that the developmental aspects could be better observed. This methodological strategy would also make it possible to monitor the stability of the well-being throughout adolescence, given that there is no consensus in the studies in relation to this aspect.

\section{References}

Bastian, B., Kuppens, P., De Roover, K., \& Diener, E. (2014). Is valuing positive emotion associated with life satisfaction? Emotion, 14(4), 639-645. doi:10.1037/ a0036466

Benatuil, D. (2004). El bienestar psicológico en adolescentes desde una perspectiva cualitativa [Psychological wellbeing in adolescents from a qualitative perspective]. Psicodebate: Psicologia, Cultura y Sociedad, 3, 43-58. Retrieved from http://www.palermo.edu/cienciassociales/ publicaciones/pdf/Psico3/3Psico\%2004.pdf

Benetti, S. P. C., Gama, C., Vitolo, M., Silva, M. B., D’Ávila, A., \& Zavaschi, M. L. (2006). Violência comunitária, exposição às drogas ilícitas e envolvimento com a lei na adolescência [Community violence, exposure to illicit drugs and adolescent involvement with the law]. Psico, 37(3), 279-286. Retrieved from http://revistaseletronicas. pucrs.br/ojs/index.php/revistapsico/article/view/1449

Bueno, C. M. L. B. (2006). O papel das representações sociais e da educação para o desenvolvimento da identidade de gênero [The role of social representations and of 
education in the development of gender identity]. Revista Brasileira de Crescimento e Desenvolvimento Humano, 16(3), 92-103. Retrieved from http://pepsic.bvsalud.org/ $\mathrm{pdf} / \mathrm{rbcdh} / \mathrm{v} 16 \mathrm{n} 3 / 11 . \mathrm{pdf}$

Callahan, M. R., Tolman, R. M., \& Saunders, D. G. (2003). Adolescent dating violence victimization and psychological well-being. Journal of Adolescent Research, 18(6), 664-681. doi:10.1177/0743558403254784

Camargo, S. P. H., Abaid, J. L. W., \& Giacomoni, C. H. (2011). Do que eles precisam para serem felizes? A felicidade na visão de adolescentes [What do they need to be happy? The happiness for adolescents]. Psicologia Escolar e Educacional, 15(2), 241-250. doi:10.1590/ S1413-85572011000200006

Coenders, G., Casas, F., Figuer, C., \& González, M. (2005). Relationships between parents' and children's salient values for future and children's overall life satisfaction. A comparison across countries. Social Indicators Research, 73(2), 141-177. doi:10.1007/s11205-004-3233-0

Coutinho, R. X., Santos, W. M., Folmer, V., \& Puntel, R. L. (2013). Prevalência de comportamentos de risco em adolescentes [Risk behaviors prevalence in adolescents]. Cadernos de Saúde Coletiva, 21(4), 441-449. doi:10.1590/ S1414-462X2013000400013

Dell'Aglio, D. D., Koller, S. H., Cerqueira-Santos, E., \& Colaço, V. (2011). Revisando o Questionário Juventude Brasileira: Uma nova proposta [Reviewing the Brazilian Youth Questionnaire: A new proposal]. In D. D. Dell'Aglio \& S. H. Koller (Eds.), Adolescência e juventude: Vulnerabilidade e contextos de proteção [Adolescence and youth: Vulnerability and protection contexts] (pp. 259-270). São Paulo, SP: Casa do Psicólogo.

Diener, E. (1984). Subjective well-being. Psychological Bulletin, 95(3), 542-575. doi:10.1037/00332909.95.3.542

Diener, E., Suh, E. M., Lucas, R. E., \& Smith, H. L. (1999). Subjective well-being: Three decades of progress. Psychological Bulletin, 125(2), 276-302. doi:10.1037/0033-2909.125.2.276

Farias Júnior, J. C., Nahas, M. V., Barros, M. V. G., Loch, M. R., Oliveira, E. S. A., De Bem, M. F. L., \& Lopes, A. S. (2009). Comportamentos de risco à saúde em adolescentes no Sul do Brasil: Prevalência e fatores associados [Health risk behaviors among adolescents in the south of Brazil: Prevalence and associated factors]. Revista Panamericana de Salud Pública, 25(4), 344-352. doi:10.1590/S1020-49892009000400009

Field, A. (2009). Análise de fatores exploratória [Exploratory factor analysis]. In Descobrindo a estatística usando o SPSS [Discovering statistics with SPSS] (L. Viali, Trans., 2nd ed., pp. 553-605). Porto Alegre, RS: Artmed.

Habigzang, L. F., Ramos, M. S., \& Koller, S. H. (2011). A revelação do abuso sexual: As medidas adotadas pela rede de apoio [The disclosure of sexual abuse: Adopted measures by the support network]. Psicologia: Teoria e Pesquisa, 27(4), 467-473. doi:10.1590/S010237722011000400010
Krug, E. G., Dahlberg, L. L., Mercy, J. A., Zwi, A. B., \& Lozano, R. (Eds.). (2002). World report on violence and health. Geneva, Switzerland: World Health Organization. Retrieved from http://apps.who.int/iris/ bitstream/10665/42495/1/9241545615_eng.pdf

Lei n. 11.340, de 7 de agosto de 2006. (2006, 8 de agosto). Cria mecanismos para coibir a violência doméstica e familiar contra a mulher, nos termos do $\S 8^{\circ}$ do art. 226 da Constituição Federal, da Convenção sobre a Eliminação de Todas as Formas de Discriminação contra as Mulheres e da Convenção Interamericana para Prevenir, Punir e Erradicar a Violência contra a Mulher; dispõe sobre a criação dos Juizados de Violência Doméstica e Familiar contra a Mulher; altera o Código de Processo Penal, o Código Penal e a Lei de Execução Penal; e dá outras providências. Diário Oficial da União, seção 1.

Martínez González, A. E., Inglés Saura, C., Piqueras Rodríguez, J. A., \& Oblitas Guadalupe, L. A. (2010). Papel de la conducta prosocial y de las relaciones sociales en el bienestar psíquico y físico del adolescente. Avances en Psicología Latinoamericana, 28(1), 74-84.

Martins, C., Gouveia, A., Chaves, M., Lourenço, R., Marques, S., \& Santos, T. (2014). Dating violence and nursing student well-being. Atención Primaria, 46(Supl. 5), 129-134. doi:10.1016/S0212-6567(14)70079-4

Ministério da Saúde. Conselho Nacional de Saúde. (2013, 13 de junho). Resolução n. 466, de 12 de dezembro de 2012. Aprova as diretrizes e normas para pesquisa envolvendo seres humanos [Guidelines and standards for research involving human subjects]. Diário Oficial da União, seção 1 .

Ministério da Saúde. Secretaria de Vigilância em Saúde. Departamento de Análise de Situação de Saúde. (2010). Viva: Vigilância de violências e acidentes, 2008 e 2009 [Viva: Violence and accidents surveillance, 2008 and 2009]. Brasília, DF: Ministério da Saúde.

Mosavel, M., Ahmed, R., \& Simon, C. (2012). Perceptions gender-based violence among South African youth: Implications for health promotion interventions. Health Promotion International, 27(3), 323-330. doi:10.1093/ heapro/dar041

Nurcombe, B. (2000). Child sexual abuse I: Psychopathology. Australian and New Zealand Journal of Psychiatry, 34(1), 85-91. doi:10.1046/j.1440-1614.2000.00642.x

Park, N. (2004). The role of subjective well-being in positive youth development. Annals of the American Academy of Political and Social Science, 591, 25-39. doi:10.1177/0002716203260078

Poletto, M., \& Koller, S. H. (2011). Subjective well-being in socially vulnerable children and adolescents. Psicologia: Reflexão e Crítica, 24(3), 476-484. doi:10.1590/S010279722011000300008

Reina, M. C., Oliva, A., \& Parra, A. (2010). Percepciones de autoevaluación: Autoestima, autoeficacia y satisfacción vital en la adolescencia [Adolescents own perceptions of self-evaluation: Self esteem, self efficacy and life satisfaction]. Psychology, Society, \& Education, 2(1), 
47-59. Retrieved from http://www.psye.org/articulos/ Reina\%20et\%20al\%20definitivo.pdf

Saffioti, H. I. B. (2008). Gênero: Ontogênese e filogênese [Gender: Ontogeny and phylogeny]. In S. L. Kato (Org.), Manual de capacitação multidisciplinar [Multidisciplinary training manual] (pp. 91-124). Cuiabá, MT: Departamento Gráfico/Tribunal de Justiça do Mato Grosso.

Sarriera, J. C., Saforcada, E., Tonon, G., La Vega, L. R., Mozobancyk, S., \& Bedin, L. M. (2012). Bienestar subjetivo de los adolescentes: Un estudio comparativo entre Argentina y Brasil [Subjective well-being of the adolescents: A comparative study between Argentina and Brazil]. Psychosocial Intervention, 21(3), 273-280. doi:10.5093/in2012a24

Segabinazi, J. D., Giacomoni, C. H., Dias, A. C. G., Teixeira, M. A. P., \& Moraes, D. A. O. (2010). Desenvolvimento e validação preliminar de uma Escala Multidimensional de Satisfação de Vida para Adolescentes [Development and preliminary validation of a Multidimensional Life Satisfaction Scale for Adolescents]. Psicologia: Teoria e Pesquisa, 26(4), 653-659. doi:10.1590/S010237722010000400009

Segabinazi, J. D., Zortea, M., Zanon, C., Bandeira, D. R., Giacomoni, C. H., \& Hutz, C. S. (2012). Escala de Afetos Positivos e Negativos para Adolescentes: Adaptação, normatização e evidências de validade [Positive and Negative Affect Scale for Adolescents: Adaptation, standardization and validity evidence]. Avaliação Psicológica, 11(1), 1-12. Retrieved from http://pepsic.bvsalud.org/scielo.php?script=sci_arttext\& pid $=$ S1677-04712012000100002

Serafini, A. J., \& Bandeira, D. N. (2011). A influência da rede de relações, do coping e do neuroticismo na satisfação de jovens estudantes [The influence of the network of relationships, coping and neuroticism on the life satisfaction of young students]. Estudos de Psicologia, 28(1), 15-25. doi:10.1590/S0103-166X2011000100002

Strelhow, M. R. W., Bueno, C. B. O., \& Câmara, S. G. (2010). Percepção de saúde e satisfação com a vida em adolescentes: Diferença entre sexos [Health perception and satisfaction with life in adolescents: Difference between the sexes]. Revista Psicologia \& Saúde, 2(2), 4249. Retrieved from http://www.gpec.ucdb.br/pssa/index. $\mathrm{php} / \mathrm{pssa} /$ article/view/62/99

Traverso-Yépez, M. A., \& Pinheiro, V. S. (2005). Socialização de gênero e adolescência [Gender socialization and adolescence]. Estudos Feministas, 13(1), 147-162. doi:10.1590/S0104-026X2005000100010

Vera, E., Thakral, C., Gonzales, R., Morgan, M., Conner, W., Caskey, E., . . . Dick, L. (2008). Subjective well-being in urban adolescents of color. Cultural Diversity \& Ethnic Minority Psychology, 14(3), 224-233. doi:10.1037/10999809.14.3.224

Watson, D., Clark, L. A., \& Tellegen, A. (1988). Development and validation of brief measures of positive and negative affect: The PANAS scales. Journal of Personality and
Social Psychology, 54(6), 1063-1070. doi:10.1037/00223514.54.6.1063

World Health Organization. (2014a). Strengthening the role of the health system in addressing violence, in particular against women and girls, and against children. SixtySeventh World Health Assembly Resolution. Retrieved from http://apps.who.int/gb/ebwha/pdf_files/WHA67/ A67_R15-en.pdf?ua=1

World Health Organization. (2014b). Health for the world's adolescents: A second chance in the second decade. Retrieved from http://apps.who.int/adolescent/seconddecade/

Zavaschi, M. L., Benetti, S., Polanczyk, G. V., Solés, N., \& Sanchotene, M. L. (2002). Adolescents exposed to physical violence in the community: A survey in Brazilian public schools. Revista Panamericana de Salud Pública, 12(5), 327-332. doi:10.1590/S1020-49892002001100006

Doralúcia Gil da Silva is a Ph.D. candidate of the Graduate Program in Psychology at the Universidade Federal do Rio Grande do Sul.

Débora Dalbosco Dell'Aglio is a Professor of the Instituto de Psicologia at the Universidade Federal do Rio Grande do Sul.

Received: July 6, 2015

1st Revision: Nov. 6, 2015 Approved: Dec. 21, 2015

How to cite this article:

Silva, D. G., \& Dell'Aglio, D. D. (2016). Exposure to domestic and community violence and subjective wellbeing in adolescents. Paidéia (Ribeirão Preto), 26(65), 299-305. doi:10.1590/1982-43272665201603 